\title{
A Whole World: REAding Global Byzantium Through Coptic ART
}

\section{ENGY ESHAK YOUSEF HANNA \\ Faculty Of TOURISM AND Hotels, Minia University}

\begin{abstract}
This paper explores the influence of the global culture of Byzantium on the social life of Egyptians in the Early Byzantine period, focusing on the appearance of common women on Coptic artefacts as one of the implications of this influence. The communication between Egypt and other parts of the empire secured its economic and cultural integration into the broader Byzantine culture, which viewed the Mediterranean provinces as parts of a whole world. To common women in Egypt, imperial women were the most significant manifestation of this global culture. They were presented by the imperial house, and perceived by locals, as paradigms of feminine power because of their reputed wealth, virtue, nobility and wisdom. Therefore, visual representations of women on Coptic artefacts display signs of feminine power that were inspired by the appearance of imperial women. This feature underlines the significance of Coptic art as a supplementary source for women's histories, which have been neglected, biased or omitted in contemporary literary sources.
\end{abstract}

KeYWORDs: Women, Gender, Global Byzantium, Coptic Art, Byzantine Art, Empress, Social History

\section{INTRODUCTION}

Upon Constantine's defeat of Licinius in 324, Egypt became a part of the early Byzantine world for more than three centuries. Most frequently, Christian sources portrayed Egypt as alien to the empire due to the successive religious struggles between the Coptic Church and the imperial house (Bagnall 2007). However, contemporary evidence from Egypt and other provinces suggests that the impact of the global culture of Byzantium on Egyptian society was more powerful than the difference in religious affiliations. It is from this viewpoint that I will investigate how the local culture of Egypt 
absorbed the global culture of Byzantium, focusing on one aspect: women's appearance in Coptic artworks. ${ }^{1}$ This involves analysing the cultural implications of embracing imperial appearance and the social perception of global Byzantium.

A few limitations need to be noted at the outset. The term "Byzantium" refers to the Byzantine Empire: the direct continuation of the Roman Empire in the eastern half of the Mediterranean basin (Mango 2002: 2). Within this context, one definition of the term "global Byzantium" could refer to the connections between distant or neighbouring parts of the Byzantine Empire and its impact on people's lives. One aspect of this impact was the mimicking of imperial appearance by upper-class women all over the empire, including Egypt. In this respect, the word "appearance" means the outward impressions, indications, and circumstances that are visually expressed through women's attire, poses, and surroundings. Unfortunately, textual sources in this respect are very rare. This lack of adequate evidence highlights the significance of visual culture as supplementary historical evidence on female life in the Early Byzantine period. Therefore, the study mainly considers the visual representations of women in Byzantine art and Coptic art-more specifically, the artefacts that were used and produced in Egypt in the Early Byzantine period.

\section{Previous Research}

Previous studies on Byzantine women presented useful perspectives about the cultural and social framework that contributed to shaping women's lives. Some significant works treated imperial and aristocratic women from Byzantium, who held a powerful and respected place in society, for example, Judith Herrin's article "The Imperial Feminine in Byzantium" (Herrin 2000: 7 and n. 11).

Some works treated the social history of common women all over the empire. Gillian Clark's Women in Late Antiquity discusses women's legal rights and boundaries, and the social definitions that affected women's appearance in this male-made society (Clark 1993). The exhibition catalogue Byzantine Women and Their World introduced a

\footnotetext{
${ }^{1}$ The term "Coptic" is derived from the Greek word Aegyptus, a term that was used by Greeks to designate Egypt (Gabra 2014: 2). In the context of this study, I use the term "Coptic" to refer to the dominant style of art in Late Antique Egypt (Gabra and Eaton-Krauss 2007: xiii).
} 
better understanding of women's everyday experience (Kalavrezou 2003b).

\section{METHODOLOGY}

This paper will discuss women's appearance from a social-context, art-historical approach. I will compare women's depictions on Coptic wall paintings, mummy portraits, and tapestry textiles from Egypt with representations of imperial and aristocratic women elsewhere. This involves considering these depictions in the light of surviving archaeological examples of dress and jewellery from Egypt. It also explores these depictions in the light of contemporary literature that deals with women's appearance and social life, such as the exhortations of early Church Fathers and historical records. My primary focus is on answering some basic questions: How were women depicted? How were they influenced by the global culture of Byzantium? What are the social implications of embracing a global style of appearance? The discussion will proceed in several steps. I will begin by setting the scene, then exploring the means of communication between Egypt and other parts of the Byzantine Empire, then investigating common women's perceptions of imperial women, and ending by analysing imperial women's influence on common women's appearance.

\section{SetTing THE SCENE}

The world of Early Byzantine Egypt lay at the point of intersection of many cultures and ideologies. At this time, Christianity imbued every aspect of society with its own special flavour. Classical survivals, represented in the two cohabiting cultural strains, the Ancient Egyptian and Greek heritages, had a great impact on the thought system and material culture of the Copts. ${ }^{2}$ Social hierarchy was influenced by wealth, occupation, family background, and membership in honorific councils. Although there is hardly any neat dichotomy that can be established, two socio-economic classes can be recognized: the upper-class honestiores, and the lower-class humiliores (Török et al 2005: 20-23). The upper class encompassed smaller sub-classes, at the top of which stood high officials (members of city councils, magistrates, and the "gymnasial" class), and the propertied classes of the cities like Oxyrhynchus, Hermopolis,

\footnotetext{
${ }^{2}$ This blend of classical heritage gave rise to original work in visual arts, literature, and performing arts that contributed greatly to shaping women's interests and preferences, Bagnall 2002: 252.
} 
Antinopolis, Panopolis, and Arsinoe. ${ }^{3}$ These groups comprised urban residents who were wealthy enough to live from the income of their property. At the bottom of this class stood village landowners, who had enough land to live on and were engaged in various entrepreneurial activities. The lower class included all the lower echelons of Early Byzantine society: poor villagers, unskilled labourers, servants, slaves, and morally compromised classes like dancers and prostitutes (Keenan 2007: 226-229). The women who are the subjects of this study are those who belonged to the well-to-do upper class, those who could have afforded the luxury objects that form my focus. In this world, how was Egypt, as a Byzantine province, integrated into the global culture of Byzantium? What were the major means of cultural communication?

\section{Means OF COMMUnication Between EgYPT AND OTHER PARTS OF THE EMPIRE}

Of course, there was no Byzantine concept of the global middle

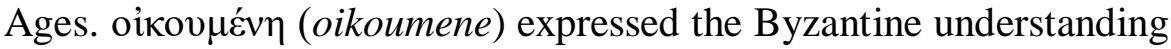
of a global perspective. The meaning of this term is "the inhabited world." It had various resonances in Byzantium. Most prominently, it was used to designate the world as a whole (James 2010: 7). Therefore, one of its implications was the interconnectedness of the various parts of the empire, whether distant or nearby. Within this context, exploring the features of global Byzantium in Egypt requires considering the means of communication that connected it with Constantinople and other parts of the empire most prominently, trade, tourism, pilgrimage, imperial legislation, and imperial representations on coinage and statuary.

The economic integration of Egypt into the empire was achieved through trade and taxes. The two ports of Alexandria and Pelusium played the key role in external trade. ${ }^{4}$ Alexandria specifically enjoyed a regional and imperial economic importance thanks to its remarkable geographical location between continents and its network of canals linking it to other Egyptian cities and villages. This unique location made sea and river sailing possible and facilitated internal and external commerce. This is emphasized by the excavations at Kom el-Dikka, where a surviving graffito depicts a number of seagoing

\footnotetext{
${ }^{3}$ For further reading about urban communities in Late Antique Egypt see Alston and Alston 1997: 199- 216; For further information about village, landowners, Alston 1995: 117.

${ }^{4}$ For further reading see Carrez-Maratray 1999.
} 
ships and river craft (Haas 1997: 22). Obviously, imported luxury goods, like clothing and jewellery, were only affordable for the aristocratic circles of Alexandria and other urban communities. Nevertheless, their styles and decoration affected the production of these goods in Egypt. In Alexandria, workshops of luxury goods absorbed, developed, and transferred foreign impact to other parts of the Egyptian province through internal trade. ${ }^{5}$ Apparently, imported goods, and locally made ones that carried foreign influences, in addition to imperial representations in the Egyptian province like statuary and coinage, were probably the most significant means of cultural communication, for they were easily accessible by a large sector of society.

Alexandria, as a cosmopolitan city, also played a key role in the cultural integration of Egypt into the empire. It was a central destination for tourists of different nationalities. This significance was recognized by emperors themselves, like Emperor Caracalla, who describes the tourists of Alexandria as "those who congregate here with the object of viewing the glorious city of Alexandria or come down for the sake of enjoying a more civilized life or for incidental business" (Gagos and Potter 2006: 66). The cultural importance of Alexandria was also a result of the religious shrines it hosted, which ensured a steady stream of pilgrims drawn from many different religious persuasions (Haas 1997: 22). For example, to the west of Alexandria, the monastery of Abu Mena enjoyed a global fame at the time (Hunter-Crawley 2017: 187-202). The monastery of St. Enaton was also a center of attraction (Heinen 1991: 1:101).

The exchange of students and the educational importance of Alexandria also enhanced the communication between Egypt and other Mediterranean provinces. According to contemporary literary sources, some students all over the empire partitioned their education, moving progressively from towns to cities and finally to the great educational magnets of Athens, Constantinople, Antioch, and Alexandria. During this period, Alexandria was a remarkable educational center in the exact sciences (physics, mathematics) as well as in Neoplatonic philosophy. ${ }^{6}$ Foreign students, generally

\footnotetext{
${ }^{5}$ For example, the Edict on Maximum Prices shows that Alexandrian workshops imitated more expensive garments from Cilicia (Haas 1997: 42). ${ }^{6}$ The term "Neoplatonism" refers to a philosophical school of thought that first emerged and flourished in the Greco-Roman world of Late Antiquity, roughly from the time of the Roman Imperial crisis to the Arab conquest. Neoplatonism was the dominant philosophical ideology of the period,
} 
members of the upper class, went to Alexandria to study rhetoric, philosophy, theology, law, and medicine. Similarly, local students travelled and received their higher education abroad. Libanius, a famous Greek rhetorician, mentions that young men from Egypt attended his school. ${ }^{7}$ This communication created an adequate environment for cultural exchange.

Within the same context, the cultural integration of Egypt into the Byzantine world was also influenced by the temporary stay of imperial officials in Egypt. Though some sources portrayed them as enemies who were rejected by the local people, other sources show that they were formally welcomed by locals using poems (Fournet 1999). Similarly, wealthy Egyptians who lived temporarily in Constantinople could have brought features of the global culture of Byzantium back to Egypt. Papyri from Egypt show that wealthy Egyptians sometimes lived in Constantinople. ${ }^{8}$ Flavius Dioskoros, the well-known sixth-century notary, poet and lawyer, travelled widely and spent two years in Constantinople (MacCoull 1988: 8-15).

Imperial legislation had limited influence on the transfer of the global culture of Byzantium to provinces like Egypt that were far from the capital. Its impact can be attested more clearly in public, procedural, or formal issues. For example, the exclusions imposed on women in Byzantine Egypt were in accordance with the legal ones: no woman filled official posts, served as a witness in a contract or a will, or defended the interests of a third party before a court with the sole exception of her children (Beaucamp 1992: 5-31). So, it could be assumed that the previously discussed means of communication helped local Egyptians absorb some features of the global culture. When considering the case of common women specifically, the most significant manifestation of this global culture was the physical and social image of imperial women. How did common women of Egypt perceive imperial ones?

\section{COMMON WOMEN'S PERCEPTION OF IMPERIAL WOMEN}

The class of imperial women included a number of sub-classes, at the top of which stood the empress. She was seen as the ultimate perfect standard for all women of the empire. Her social image in the

offering a comprehensive understanding of the universe and the individual human being's place in it; Wildberg 2016.

${ }^{7}$ Or. 31.40; Cribiore 2007: 47-66.

${ }^{8}$ P.Oxy. LXIII 4397. 
provinces was determined by the way she developed ties with the common populace in these provinces and the way she was presented by the imperial house. Since the reign of the Julio-Claudian dynasty, many female members of imperial families were prominent and influential, and had links with Egypt through property and ancestry. Some were even deified by the local population. With the Christianization of the empire, imperial cults ceased. However, under the Theodosean dynasty (AD 379-450), imperial properties in Egypt were again assigned to women (Holum 1982). ${ }^{9}$ Some empresses owned large estates, like Empress Aelia Eudocia who possessed vast areas of land in the Oxyrhynchite nome in the fifth century (Palme 2007: 263). This sort of contact emphasized the patronage of empresses among local people in the provinces, men and women alike. A draft of a sixth-century petition, written by Dioskoros of Aphrodite, to Empress Theodora, wife of Emperor Justinian, implies that the imperial estates at the village of Aphrodite had been assigned to her, and that she could exert influence on imperial administrators in Egypt in favour of her dependants, in this case villagers who were tenants of her land (Rowlandson 1998: 45-46). ${ }^{10}$

Religious patronage was another important element that shaped the image of imperial women in the minds of Early Byzantine commoners. Many empresses contributed a great deal to the religious life of the empire. They endowed charitable institutions, churches, relics, and icons. For example, the foundation of many churches in Egypt was attributed to Empress Helena, particularly those of the Red and White Monasteries near Souhag in Upper Egypt (Morgan 2016: 68). Hence, it could be assumed that the large landholdings of imperial women and their charity works in provinces depicted them as virtuous, wealthy figures.

The appearance of empresses in official art also tells something about how they were promoted and presented to common people. In this respect, evidence from Egypt is very scarce. However, one may get an idea from the surviving representations of imperial women in other provinces, as they express a broader tendency of official imperial art all over the empire. Broadly speaking, representations of empresses most prominently appear in stone statuary, coinage, mosaics and small lead-filled figurines. These media were placed in public places in order to disseminate their power. Portraits in

\footnotetext{
${ }^{9}$ P.Mil.II 63; P.Oxy. 13582; P.Oxy. 3585.

${ }^{10}$ P.Cair.Masp. III 67283.
} 
sculpture continued until the sixth to seventh century, ending around the time of Iconoclasm. ${ }^{11}$ This does not mean that the statues disappeared all at once. They continued to decorate public spaces for centuries. Surviving examples of imperial statuary show that they were erected in highly visible and accessible places, so the common people could see them clearly. In Constantinople, for example, a significant number of ancient statues remained on view in public places, especially in the Hippodrome (Gittings 2003a: 35-65).

In addition to stone sculpture, remarkable examples of representations of empresses can be seen on the mosaics and mural paintings that decorated public spaces. ${ }^{12}$ Some depictions present empresses in association with grand concepts such as Renewal, Magnanimity and Foundation. For example, a sixth-century mosaic floor fragment, now exhibited in the Metropolitan Museum, depicts the personification of Foundation, Ktisis, with empress-like appearance, with her jewels and cornucopia-attributes of beauty, wealth and abundance (Evans et al. 2001: 16).

This link points to an intentional symbolic connection between the empress and concepts that were already embraced by the Early Byzantine audience, shaping female dignity and introducing her as a role model for women all over the empire. Small-scale figurines were also shaped in the likeness of empresses.

For example, lead-filled bronze counterweights, which were used in the marketplace in weighing everyday commodities, took the form of imperial busts. Most of the weights preserved from the fifth to the seventh century take the form of either an empress or the goddess Athena (Merhav 1981: 223-224). The presence of these imperial busts in the marketplace and their association with the goddess of justice has been interpreted as an imperial guarantee of the fairness of commercial transactions (McClanan 1997).

Following the example of empresses, other imperial women, like ladies-in-waiting, were portrayed with signs of elaborate dress and jewellery. Their appearances were inspired by the empresses' apparel but were less sumptuous. Procopius' Secret History and a Ravenna mosaic (fig. 1) show that during the reign of Empress Theodora the

\footnotetext{
${ }^{11}$ For a general discussion of these early surviving portraits of women, Kalavrezou 2002: 241- 242.

${ }^{12}$ For example, the mosaic depicting Empress Theodora and court ladies in the church of San Vitale in Ravenna; Zwirn 1979b: 77-78.
} 
appearance of attendants and audiences at court rituals was heightened on the Persian model — a style famous for its love of splendour and for sumptuous jewelled adornment of persons and surroundings. As the supreme model of Byzantine women, Empress Theodora wore the most heavily jewelled ornaments and richest fabrics along with her imperial insignia. Her attendants were depicted with sumptuous dress and jewellery, but displaying a less elaborate appearance than Theodora's.

The level of elaborateness of imperial women was determined according to a carefully graduated system running from titled women, down through high-ranking women and ladies of the court, to wives of officials and women of lower rank (Connor 2004:145). Considering the whole image of imperial women, it could be assumed that their representations on the various media featured them as paradigms of power, virtue, and wisdom, being young, healthy, and luxuriously attired.

If the primary intention of the imperial house and official artists was to promote this idealistic image, did common women receive this message as planned? There is hardly any direct evidence of the way common people in Egypt perceived the imperial images. A faint idea could be gained from subsidiary remarks of texts from other provinces. For example, a historical account by Sozomenos describes people's reactions to the famous silver effigy of the fifth-century empress Eudoxia, which stood on a porphyry column in the Augustaion. ${ }^{13}$

The statue commemorated Eudoxia's acclamation as augusta and was dedicated "with applause and popular spectacles of dances and mimes, as was then customary on the erection of the statues of the empress" (Herrin 2000: 7, n. 11). The reliability of such accounts is questionable, as they could be merely motivated narratives. However, a more reliable perspective on the perception of imperial women by common women can be gained by investigating the appearance of upper-class women in Egypt as reflected in Coptic artworks, and tracing the influence of imperial women's appearance on them.

13 The Augustaion (or Augusteum) was an enclosed open space in Constantinople, situated south of Hagia Sophia, with many key monuments located in the vicinity. While the Augustaion changed over time, it was always of great ideological and symbolic importance, in part due to its connection with Hagia Sophia and the Great Palace. Angelova 2015: 172. 


\section{IMPERIAL WOMEN'S INFLUENCE ON COMMON WOMEN'S APPEARANCE}

In a world where women's lives mainly centred around home and their mobility was restricted to the private domain, one might think that their priorities were limited to domestic work, and bearing and raising children (Kalavrezou 2003b: 13). However, as strong as the ideology was, reality was quite different. Visual representations demonstrate that common women from Egypt, as in other provinces, were interested in displaying signs of power, following the example of imperial women. The influence of the appearance of imperial women on that of common women of Egypt can be determined by a comparison between the representations of these two classes. It reveals some common features incorporated into their dress, jewellery, hairstyles, poses, gestures, archaeological background, and the people depicted with them. In both groups of representations, these visual elements were not portrayed haphazardly, but were intended to act in a semiotic way to display women's wealth, virtue, nobility, and wisdom.

\section{SigNS OF WEALTH}

Clothing was one of the most obvious indicators of wealth. One significant feature of elaborate clothing was layering of dress. In Egypt, women's garb was composed of two basic components: tunics below, with overwear above (Hanna 2017: 47-90). The most common clothing style was composed of a baggy ankle-length tunic and a large shawl or palla headdress covering the head, shoulders, and chest, as depicted on tombstones (fig. 2). Some representations show women bareheaded, wearing an elaborately embroidered tunic, as depicted on tapestry portrait busts (fig. 3) (Gabra and EatonKrauss 2007: 172, no. 110; Maguire et al. 1999: 156, fig. C 15). It could be assumed that the first style represents the way women appeared in public places, as it is depicted on publicly displayed objects. This style of drapery resembles the way court ladies, attendants of Empress Theodora, appeared on the mosaic in the church of San Vitale in Ravenna (fig. 1) (Zwirn 1979b: 77-78).

The material of the dress also acted as a marker of wealth and status, the most important being silk, gold thread, and purple-dyed clothing. According to the fifth-century bishop Paulinus of Nola, many elite women throughout the empire delighted in luxurious display, wearing "long dresses bright with purple and rustling with gold" (Paulinus of Nola 1975: 247-248). These materials were theoretically imperial 
preserves, by law. There was a special imperial office charged with the keeping of the silks owned by the emperors, who bestowed silken regalia upon their appointed officials and gave donations of them to western rulers (Thomas and Harding 1990: 15-24; Török 2005: 250251). However, silk finds from Egypt, specifically Panopolis (Akhmim), show that this law was ignored in practice. ${ }^{14}$ Similarly, the use of real purple-dyed fabric for whole garments was also reserved for the emperor. A law of Theodosios I established the imperial monopoly on dyeing and producing purple textiles; it was also included in the Codex Justinianus (Török 2005: 250-251). Because of its scarcity and the honour attached to purple dye, it was the preferred dye for aristocratic and upper-class women. The previously mentioned mosaic of Ravenna (fig. 1) depicts Empress Theodora dressed in a cloak wholly dyed with purple (Zwirn 1979b: 77-78). There is hardly any comparable archaeological example from Egypt. Excavations have revealed only decorative purple insets that were once fixed in linen tunics and shawls. Nevertheless, a mummy shroud from Antinopolis, now exhibited in the Louvre, depicts a well-attired woman wearing a richly decorated mantle over a purple tunic, held in place with a buckled belt (Cortopassi 2000: 152).

Dress decoration was also a marker of wealth and a feature inspired by the global style of dress. All over the empire, the clothing of the upper classes was elaborately decorated by jewel inlays or tapestry technique. There is hardly any excavated example from Egypt for clothing decorated with jewel inlays. However, underground burials revealed many embroidered tunics, and decorative bands and insets in tapestry. Such decoration was costly and could be only afforded by the upper class, because it was executed by a specially trained professional; he was recognized in a fourth- to eighth-century papyrus as an artisan trained in the special technique of the flying shuttle (Maguire 2007: 66; Török 2005: 252-254). The cost was implied by Asterius, the bishop of Amaseia, when he condemned richly decorated garments because of the money spent on them (Clark 1993: 107; Maguire 2007: 66). Within this context, members of the upper class used embroidered dress as a marker of their status.

The shape, the design and the location of tapestry insets in women's wear from Egypt are similar to the dress decoration of imperial and well-to-do women throughout the empire. A sixth-century mural

${ }^{14}$ Thomas 2007: 145; for further information about Coptic silk textiles, Beckwith 1989: 39. 
from Antinopolis portrays the most common design of women's dress decoration. It depicts a woman (fig. 4), identified by an inscription above her head as "Theodosea," wearing an ankle-length, sleeved tunic, with two decorative clavi on the shoulders reaching to the waist, ending with rounded medallions. Decorative bands of tapestry frame the borders of the tunic and two squared medallions decorate its lower part (Bénazeth 2000: 106-107). The decoration of the lower part of Theodosea's tunic resembles the decoration of the tunics of Empress Theodora and the court ladies in the mosaic of San Vitale in Ravenna (fig. 1) (Zwirn 1979b: 77-78). This style is also comparable to women's garments in other Byzantine provinces as suggested by their depiction on wall paintings and mosaics, like a fifth-century mosaic at Sidi Ghrib, in Tunisia, now in the National Museum of Carthage, Tunisia (Ennabli 1986: 1087-1101).

Another type of women's wear from Egypt displays features of imperial fashion. It has been excavated from a tomb at Antinopolis, now exhibited in the Louvre. It was identified as a shirt or an undergarment (fig. 5). The garment is pierced by a large neck slit, framed by a tapestry band with geometrical patterns upon a dark blue background. The front is decorated with vertical rows of three dots alternating with stylized leaves, which look like the almond leaves used in the necropolis of Antinopolis. This style of decoration resembles the design of the court ladies' dress in the mosaic of San Vitale in Ravenna (fig. 1) (Ball 2005; Garland 1999).

In visual representations, jewellery was surely the most prominent manifestation of wealth. Most of the excavated pieces, like those found in the so-called hoard of Assiut, are made of gold mounted with pearls, emeralds, and sapphires (Petrina 2014: 31-43). They show a delicate technique of manufacture and excellence of workmanship. Obviously, they display a Constantinopolitan influence. One feature of this influence is the homologous style of jewellery components, where hair ornaments, earrings, and necklaces had the same style. This feature can also be traced on women's representations on mummy portraits, wall paintings and tapestry textile, like the previously mentioned tapestry portrait bust in the Rose Choron private collection (fig. 3) (Maguire et al. 1999: 156, fig. C 15). The jewellery depicted on this tapestry is similar to imperial jewellery in terms of their composition and colours. They are comparable to those depicted in mosaics, coins, portraits, and counterweights, like a counterweight now exhibited in the Metropolitan Museum of Art (Franken 1994: 97). 
Imperial insignia inspired Coptic artists, who borrowed some features and developed them, producing distinctive designs. For example, in the Antinopolis mural (fig. 4), Theodosea's coiffure is ornamented with a hairnet (fig. 6), painted in yellow, presumably imitating the colour of gold. On either side of the hairnet, a golden string with pendants attached to it is hanging down and attached in the back. These strings could have been inspired by the imperial pendalia, the strings of pearls attached to empresses' crowns. This feature first appeared on coins of the fifth-century empress Licinia Eudoxia (Herrin 2001: 60-61). A verse in a poem written by Nonnos of Panopolis implies that a bride might be adorned with these strings at a wedding celebration. ${ }^{15}$

Crowns can also be seen adorning women's representations on mummy portraits and tapestry portrait-busts. They display remarkable similarity to imperial crowns. For example, the previously mentioned tapestry fragment from the Rose Choron Collection depicts a full-faced, rosy-cheeked woman whose coiffure is decorated with a jewelled crown (fig. 3) (Maguire et al. 1999: 156, fig. C 15). This crown consists of two horizontal rows of white circular jewels, interrupted by a rectangular medallion (fig. 7). The medallion is framed by a yellow border and filled with two triangular inlays, woven in green and red woollen yarns. Judging from its colours, the crown could be an imitation of an actual piece made of a golden framework, as suggested by the yellow border, with inlays of white quartz or pearls, green emerald, and red garnet fixed in it (Drauschke 2010: 50). The crown matches the sculpted crowns adorning the heads of imperial stone portraits, like the portrait of Emperor Arcadius in the Istanbul Archaeological Museum and the statuette of Aelia Flacilla in the Bibliothèque Nationale, Cabinet des Médailles, in Paris.16

The necklaces depicted in artworks also display features of the global style of jewellery. In the tapestry of the Rose Choron Collection mentioned earlier (fig. 3), a woman is wearing a necklace composed of stone inlays of different sizes, shapes, and colours, fixed on a colourless thread or wire and arranged in two rows (fig. 8) (Maguire et al. 1999: 156). The colours of the inlays are similar to the crown's inlays: green, red, and white, imitating emerald, garnet, and pearls or

\footnotetext{
${ }^{15}$ Nonnos of Panopolis, Dionysiaca, 5.121, in Rouse 1940: no. 344.

16 Portrait of Emperor Arcadius, Istanbul Museum, inv. no. 5028; Breckenridge 1979: 26-27.
} 
quartz. This type of necklace is frequently attested in archaeological finds. It resembles the necklaces of Empress Theodora and one of the court ladies on the Ravenna mosaic (fig. 1) (Zwirn 1979b: 77-78).

Hairstyle was also a signifier of wealth and global influence. According to Bishop Paulinus of Nola, elite women wore their hair uncovered and piled high, "structured and castellated with layers of ropes and interwoven locks" (Paulinus of Nola 1975: 247-248). This style of coiffure is attested in pictorial representations of women in Egypt. For example, Theodosea's coiffure in the Antinopolis mural (fig. 4) is composed of several tiers of curved locks arranged one above the other (fig. 9). This style is comparable to the hairstyle of a woman's head carved on the head of a bone hairpin in the Dumbarton Oaks Museum (fig. 10) (Weitzmann 1972: 26, fig. 14). The hairpin is from Egypt and dates to the fifth century. It displays a very high, wig-like coiffure whose stylized design consists of concentric lines crossed by radiating lines. At the back of the head, the hair, which is parted in the centre, is swept up from a chignon at the nape of the neck and thus supports the high coiffure of the front. This hairstyle is comparable to the famous coiffure which was worn by women during the period of the Flavian emperors, as seen in the famous Fonseca marble bust now exhibited in the Hall of Emperors, Capitoline Museums, Palazzo Nuovo, in Rome (Bartman 2001: 1-25). This is the style that Juvenal mocked when he commented on hairstyles of women of his day: "So important is the business of beautification; so numerous are the tiers and storeys piled one upon another on her head! In front, you would take her for an Andromache [tall]; she is not so tall behind: you would not think it was the same person." ${ }^{17}$ It is thus is possible to assume that the hairstyle continued in use for centuries.

Side buns seem to have been popular in Early Byzantine Egypt. They can be seen on several Coptic artefacts of different media: a wooden cover of a large casket (fig. 11) in the State Museum in Berlin, a pottery jar in the Coptic Museum in Old Cairo, and a tombstone in the Alexandria National Museum (Mietke 2000: 155; Habib 1967: 126-128, pl. 80; Rutschowscaya 2000: 125). In this fashion, the hair is parted from the centre and drawn backwards to the nape of the neck, then parted into two side locks, which are rolled up to form two side buns. They were pinned to the head right behind the ears by means of hairpins. This hairstyle is also comparable to that of

${ }^{17}$ Juvenal, Satires, 6.502; Stocker 1839: 154. 
Empress Helena, as seen on a bronze follis in the Arthur M. Sackler Museum at Harvard University (fig. 12) (Gittings 2003b: 58-59, fig. 16).

In addition to women's dress, jewellery, and hairstyle, there were other elements that contributed to their display of wealth, such as luxurious space. A fifth-century wall hanging from Egypt (fig. 13), now in the Musées d'Art et d'Histoire in Brussels, was excavated in Antinopolis, in the tomb of an aristocratic man called Aurelius Colluthus. The hanging shows two busts, a man and a woman, probably Colluthus and his wife Tisois. They are luxuriously attired, looking out from the windows of their palace into the garden and sipping wine (Maguire et al. 1999: 31). The hanging shows luxurious architectural and decorative elements that actually existed in the houses of the wealthy in the Early Byzantine period. The arches overlooking the garden are best known in Byzantine villas, as suggested by a fifth-century mosaic of Dominus Julius in Carthage, and the representation of the villa of Secundus on the silver casket of Projecta in Rome (Nevett 2010: 120; Shelton 1979: 330-332, no. 310). This portrayal shows some similarity to the representations of imperial women, as in the mosaic of Theodora in Ravenna (fig. 1). The mosaic shows the empress with her attendants within luxurious settings, expressed by the vaulted doorways draped with curtains, decorative friezes, and splendid columns (Zwirn 1979a: 76-77, nos. $65,66)$. Contemporary literature also emphasised the significance of luxury houses as a measure of social status. Nonnos in the Dionysiaca give a detailed description of Harmonia's palace, where the couple, Harmonia and Cadmus, are going to meet for their marriage (Rouse 1940: 3.124-183; Miguélez-Cavero 2008: 136). His description emphasises the lavish setting, and he provides detailed observations of some of the parts and materials of the palace and elements of the garden (Miguélez-Cavero 2008: 135-138).

It is clear that upper-class women in Egypt were frequently portrayed in association with imperial women by displaying visual signs of wealth: elaborate dress, sumptuous jewellery, elegant hairstyle, and luxurious space. But as important as women's wealth was, their virtue was an even more crucial aspect of their character, which needed to be proved and displayed by women throughout the empire.

\section{SigNS OF VIRTUE}

Virtue signalling, although out of favour in our modern sensibilities, was a social phenomenon deeply rooted in cultures of shame and 
honour like Early Byzantium. In this kind of male-made society, women's virtue was defined by their conformity to the gender-based norms of proper appearance and behaviour. Therefore, the display of women's virtue through visual media was popular in all Byzantine provinces, as it was rewarded by social respect. Women's representations in Coptic art imply three signs of virtue: modest appearance, prayer attitude, and symbols of almsgiving. In some representations women share these virtues with their husbands.

As previously discussed, the representations of women on publicly displayed objects showed them with a modest appearance with baggy, shapeless, ankle-length clothes and a head cover (fig. 2). ${ }^{18}$ This look coincides with St. Pisentius' description of modest women in his homily The Life of Onophrius. ${ }^{19}$ According to Pisentius, a pious woman was expected to cover her head and body totally in public places. His main concern was apparently the potential harm that women's visibility might do to male viewers. According to this ideology, women were also asked to denounce the kind of selfadornment represented in embroidered dress, sumptuous jewellery, elaborate hairstyle and cosmetics. This perception is very apparent in the writings of early Church Fathers, such as Athanasius of Alexandria, Clement of Alexandria, and John Chrysostom. ${ }^{20}$ Though this perspective expresses the ideal image of a Christian woman, it can be assumed that in real life the definition of modesty was classspecific.

To upper-class women, a modest appearance meant covering the body and the head partially with elaborate self-adornment. This assumption is supported by the remarkably different levels of modest appearance traced in both artistic and literary images of women in Early Byzantium. Upper-class women, like Theodosea in the Antinopolis mural (fig. 4), display a less modest appearance than the one depicted on tombstones (fig. 2) though both come from funerary context; she is wearing a transparent veil over an elaborate hairstyle, excessive jewellery, and cosmetics. This style of appearance is comparable to imperial women's appearance, as in a bone statuette of an imperial woman in the Art Museum of Princeton University (fig.

\footnotetext{
${ }^{18}$ Tombstone with an Orant, Coptic Museum in Old Cairo, inv. no. 8703; see Gabra and Eaton-Krauss 2007: 172, no. 110; Maguire et al. 1999: 156. ${ }^{19}$ Pisentius, "On the Life of Onophrius," partially translated in Wilfong 2002: 25-27.

${ }^{20}$ For Chrysostom's comment on feminine modesty see Schroeder 2014: $17-18$.
} 
14).21 Perhaps this was a way of depicting women as modest to emphasize their conformity to the piety standards of the day, on the one hand, but also, as wealthy upper-class women, to distance themselves from poorer classes, on the other hand. This portrayal could correspond to the biblical theme of "divine queenship," which portrays female royals as pious, beautiful, and honourable women (Deal 2009). A mural painting in a church in Baouit (fig. 15) shows a well-dressed woman with sumptuous jewellery and a crown. The figure is accompanied by a Greek inscription, 'agia ecclesia,' which means 'holy church' (Clédat 1904: pl. 14). It is noteworthy that the artist did not personify the Church as a veiled, pious woman. Instead, he gave it the appearance of a divine queen, as adopted by imperial and upper-class women. This could suggest that modesty as perceived by the upper class did not demand covering the head and body completely, nor denouncing self-adornment.

Prayer was another virtue that the upper classes took pride in displaying publicly. Common women from Egypt are sometimes represented on wall hangings as praying alongside their husbands. For example, a hanging now exhibited at the Benaki Museum (fig. 16) shows a praying couple whose status is indicated by their elaborate clothing (Cortopassi and Tsourinaki 2002: 278-279, no. 291). They appear to be standing in front of an apse of a church, suggested by a Coptic inscription recording the names of Saints Kyriakos and Makarios, probably the saints to whom the church was dedicated. Although the iconography showing men and women in prayer attitude is familiar on objects from funerary contexts, most prominently tombstones, its portrayal in the secular realm could have been inspired from an imperial practice. Justin II and his empress Sophia are shown in a prayer attitude in their half-length portraits on a gold cross in the Vatican (Maguire et al. 1999: 139). This type of portraiture could be a part of the imperial agenda expressing the support offered by the Church to the imperial couple.

Almsgiving was another virtue prominently displayed in the representations of the elite. The previously mentioned Coptic hanging in the Benaki Museum (fig. 16) was excavated from a monastery in Antinopolis. The hanging was offered to the monastery as a donation from the couple. Their portrayal in the prayer attitude, standing in

\footnotetext{
${ }^{21}$ The statuette shows a Constantinian empress wearing a palla headdress on an elaborate hairstyle and an imperial jewelled crown. Gittings 2003c: 86-87.
} 
front of the church, could have been intended to commemorate their donation and display their virtue of almsgiving. Another example of this practice is represented on a partially damaged wall painting in a church at Jeme. It commemorates a donation from the wealthy mother of a sick girl from Jeme. ${ }^{22}$ The mother financed the construction of St. Menas Chapel-a donation offered upon her daughter's healing. The mural, though devoted to St. Menas, depicts the mother and the little girl in a prayer attitude, accompanied by a Coptic inscription above their heads: "Elizabeth and her daughter." 23 This type of portrayal of wealthy donors could have been inspired by philanthropy, which was increasingly promoted as a virtue of imperial women, with Helena offered as the definitive role model. The first Christian empress and imperial patron, she was credited with the discovery of the True Cross during her pilgrimage to Jerusalem in 326, as well as the construction of the Nativity in Bethlehem (Brubaker 1997: 58). These examples show that upperclass women in Egypt were influenced by the imperial tendency to display virtue in order to gain public esteem.

\section{SignS OF NOBILITY}

Like wealth and virtue, a woman's noble ancestry was praised as a sign of honour. However, being married to a nobleman was far more important. Thus, imperial and upper-class women are frequently depicted with their husbands as significant sources of power. On the previously mentioned wall hanging from Antinopolis, now in the Musées d'Art ET d'Histoire in Brussels (fig. 13), Aurelia Tisois is represented accompanied by her husband Aurelius Colluthus (Maguire et al. 1999: 31). Both are luxuriously attired, looking out from the windows of their palace into the garden. This portrayal may have been intended as a sign of nobility. It could have been inspired by imperial art, where the nobility of empresses is emphasized by their depictions with their husbands. For example, on the obverse of a square weight from Egypt, now exhibited in the Arthur M. Sackler Museum, Harvard University (fig. 17), three figures are depicted (Heintz 2000: 26-28). Emperor Justin II occupies the prime position, in the center, wearing a three-pronged crown with pendalia at the

\footnotetext{
${ }^{22}$ The place was originally a Ptolemaic temple that is located to the east of the monumental Ramesses III gateway. It was reused as a church by the inhabitants of the Coptic village of Jeme. Wilfong 2002: 101-104.

${ }^{23}$ Many donations are recorded in the documents from the archive of Jeme legal papers found in the ruins of the Monastery of Phoibammon. Wilfong 2002: 99; cf. Wilber 1940: 97.
} 
temples. Empress Sophia, the actual wielder of power at the time, appears on the right. They are featured in the same manner on their bronze coinage, where the imperial couple is enthroned side by side in an unprecedented combination (Angelova 2003: 53-56). Perhaps this style was intended to justify the ascension of women of lower classes to the throne. For example, Theodora, wife of Justinian I, was a former circus dancer and an alleged prostitute (Procopius 1981: 8286). She was publicly displayed with Justinian in monuments in the eastern and western capitals. The two were depicted together in the centre of the triumphal mosaics on the Chalke Gate, receiving homage from conquered kings; on the altar cloth of the Hagia Sophia, performing philanthropic acts; and in the famous mosaics flanking the apse in the church of San Vitale in Ravenna, bearing gifts of gold liturgical vessels (Mango 1986: 89). Hence, upper-class women could have mimed imperial women in this custom of displaying their nobility by taking pride in their marriage to men who wielded power.

\section{SIGNS OF WISDOM}

Though women in the Byzantine world were not expected to receive any education and the vast majority were illiterate, some women in Egypt could attain higher education. Hypatia, the Greek philosopher and mathematician, moved among the highest intellectual circles in Alexandria; she was the teacher of the Neoplatonist Christian and future bishop of Ptolemais, Synesius of Cyrene (Haas 1997: 155). Some women were proud of their learning, or at least their ability to read and write, as a sign of their wisdom. Aurelia Charite, a wealthy lady from Hermopolis, took pride in her education and identified herself as 'the literate. ${ }^{24}$ This feature of global culture could have been inspired by imperial women. Empress Eusebia, wife of Constantius II, "honoured the name of Philosophy," according to Emperor Julian, and gave him "the best books on philosophy and history and many of the orators and poets" (Julian the Apostate 1962: 1:319, 329). Empress Sophia, whose name means "wisdom," was called "energetic wisdom" and praised for her "calm judgment" (Flavius Cresconius Corippus 1976: 85, 93).

This practice was sometimes interpreted in visual media. For example, from Egypt, two mummy portraits from al-Fayyoum show women in white clothes, wearing simple jewellery (fig. 18). Their names are inscribed on these portraits. They perhaps worked as teachers or philosophers, judging from their white dress, since white

${ }^{24}$ P.Charite 8 and 33 in Bagnall 2002: 241. 
was the colour worn by philosophers and other educated men.25 This could suggest that educated women were socially distinct and that they expressed their pride visually by means of a dress code. Displaying signs of wisdom on visual media could also have been inspired by imperial art. Some imperial women are portrayed on Byzantine artefacts with signs of literacy and wisdom. For example, a full-length statue of an early Byzantine empress, identified most commonly as Aelia Flacilla, wife of Theodosios I, shows the augusta with a diptych or a writing pad in her left hand (Breckenridge 1979: 26-27, cat. 20).

The wisdom of empresses was sometimes expressed visually by means of gestures. A counterweight, now exhibited in the Metropolitan Museum of Art (fig. 19), features an empress wearing the imperial diadem, a necklace, earrings, a garment tightly covering both shoulders, and a tunic (Franken 1994: 97). In her left hand she carries a small cylindrical object. In other examples, the figure is sometimes portrayed as an empress holding the seam of her outer garment with her right hand, which rests within its fold (Franken 1994: 97). The gesture of the right hand could mean the gesture of speech, or the empress grasping the seam of her garment. Both gestures are long-standing conventions in the representations of learned individuals and imply that the empress is exceptionally well educated (Angelova 2003: 53-56).

\section{CONCLUSION}

From the evidence presented here, it can reliably be assumed that, in spite of the hostility between the religious authority in Egypt and the Byzantine administration, local Egyptians embraced and developed features of the global culture of Byzantium. Upper-class women from Egypt mimicked imperial women's appearance. Apparently, this model of appearance carried social connotations further than merely representing a fashionable style. It defined female dignity and feminine power domains of the day: wealth, virtue, nobility, and wisdom. This tendency acted as a class-signifier. It established tangible but vague boundaries between subclasses of women: civilized and less civilized women, honourable and socially rejected

\footnotetext{
${ }^{25}$ Kalavrezou 2003a: 243, fig. 134. Theoretically, white was the colour of the dress of modest women in Graeco-Roman cultures. Originally, it was also the colour of the Pythagoreans. It originated from the Pythagorean prescription that one should dress in white clothes when sacrificing. Tigghelaar 2003: 301-322.
} 
women, exceptional and ordinary women. The surviving visual and literary evidence also casts light on how real life triumphed over ideology: even though the ideal image of women was to denounce self-adornment and lavish expenditure, and be restricted to the home, in the real world women were sometimes inspired by the splendour of the global culture of Byzantium, displaying their good life and status and ignoring the norms.

In the broader perspective of Coptic art, this study introduces an example of the way Coptic artists drew upon the world around them for inspiration. They borrowed signs of feminine power from the imperial representations scattered in the landscape of the urban space of Egypt. As a result, the contemporary secular environment found expression in actual everyday artefacts, specifically dress and jewellery that were used and produced by Copts. This artistic tendency to realism distinguished Coptic art as a source of social history of women, overcoming the idealized literary topos, which featured woman as a merely spiritual being, isolated from the outer world. Finally, this study suggests that integrating Coptic heritage into the larger scope of Early Byzantine material culture will promote interdisciplinary research, and will help to fill in the gaps between isolated branches of history. It also encourages researchers to cross the traditional scholarly boundaries between Coptic and Greek, which sometimes stand in the way of an integrated view of the social history of Early Byzantine Egypt.

\section{REFERENCES}

Alston, R. (1995). Soldier and Society in Roman Egypt: A Social History. London and New York: Routledge.

Alston, R., and R. D. Alston. (1997). "Urbanism and the Urban Community in Roman Egypt.” JEA 83: 199-216.

Angelova, D. N. (2003). "Empress Bust Weight and Hook." In Byzantine Women and Their World, edited by I. Kalavrezou, 53-56. Cambridge: Harvard University Art Museums; New Haven: Yale University Press.

Angelova, D. N. (2015). Sacred Founders: Women, Men, and Gods in the Discourse of Imperial Founding, Rome through Early Byzantium. Berkeley and Los Angeles: University of California Press.

Bagnall, R. S. (2002). Egypt in Late Antiquity. Princeton, NJ:

Princeton University Press. 
Bagnall, R. S. (2007). "Introduction." In Egypt in the Byzantine World, 300-700, edited by R. S. Bagnall, 1-20. Cambridge: Cambridge University Press.

Ball, J. L. (2005). Byzantine Dress: Representations of Secular Dress in Eighth- to Twelfth-Century Painting. New York: Palgrave Macmillan.

Bartman, E. (2001). "Hair and the Artifice of Roman Female Adornment." AJA 105, no. 1: 1-25.

Beaucamp, J. (1992). Le statut de la femme à Byzance (4e-7e siècle) 2: Les pratiques sociales. Paris: De Boccard.

Beckwith, J. (1989). "Byzantine Tissues." In Studies in Byzantine and Medieval Western Art, edited by J. Beckwith, 37-70. London: Pindar Press.

Bénazeth, D. (2000). "Les costumes funéraires." In L'Art copte en Égypte: 2000 ans de christianisme, exhibition catalogue, 105145. Paris: Institut du Monde Arabe and Éditions Gallimard.

Breckenridge, J. D. (1979). "Statuette of Aelia Flacilla." In Age of Spirituality: Late Antique and Early Christian Art, Third to Seventh Century, edited by K. Weitzmann, 26-27. New York: Metropolitan Museum of Art.

Brubaker, L. (1997). "Memories of Helena: Patterns in Imperial Female Matronage in the Fourth and Fifth Centuries." In Women, Men, and Eunuchs: Gender in Byzantium, edited by L. James, 52-75. London and New York: Routledge.

Calament, F. (1996). "Le 'suaire de Colluthus' ressuscité." BMRAH 67: 38 .

Carrez-Maratray, J.-Y. (1999). Péluse et l'angle oriental du delta égyptien aux époques grecque, romaine et byzantine. Cairo: Institut français d'archéologie orientale.

Clark, G. (1993). Women in Late Antiquity: Pagan and Christian Lifestyles. Oxford: Clarendon Press.

Clédat, J. (1904). Le monastère et la nécropole de Baouît. MIFAO

12. Le Caire l'Institut français d' archéologie orientale.

Connor, C. L. (2004). Women of Byzantium. New Haven: Yale University Press.

Cortopassi, R. (2000). "Linceul de femme." In L'Art copte en Égypte: 2000 ans de christianisme, exhibition catalogue, 152. Paris: Institut du Monde Arabe and Éditions Gallimard.

Cortopassi, R., and S. Tsourinaki. (2002). "Looped Pile Hanging." In Everyday Life in Byzantium, edited by D. Papanikola-Bakirtzi, 278-279. Athens: Hellenic Ministry of Culture. 
Cribiore, R. (2007). "Higher Education in Early Byzantine Egypt: Rhetoric, Latin, and the Law." In Egypt in the Byzantine World, 300-700, edited by R. S. Bagnall, 47-66. Cambridge: Cambridge University Press.

Deal, B. L. (2009). "Divine Queenship and Psalm 45." PhD diss., Brite Divinity School, Texas Christian University.

Du Bourguet, P. (1964). Catalogue des étoffes coptes: Musée national du Louvre. Paris: Éditions des musées nationaux.

Drauschke, J. (2010). "Byzantine Jewellery? Amethyst Beads in East and West during the Early Byzantine Period." In "Intelligible Beauty": Recent Research on Byzantine Jewellery, edited by C. Entwistle and N. Adams, 50-60. London: British Museum Press.

Ennabli, L. (1986). "Topographie chrétienne de Carthage." In Actes du XI Congrès International d'Archéologie chrétienne (CIAC XI), edited by N. Duval, 2:1087-1101. Rome: Collection de l'École française de Rome.

Evans, H. C., M. Holcomb, and R. Hallman. (2001). The Metropolitan Museum of Art Bulletin 58, no. 4: The Arts of Byzantium.

Flavius Cresconius Corippus. (1976). In laudem Iustini Augusti minoris, libri IV [In Praise of Justin II]. 6th century. Edited and translated by Averil Cameron. London: Athlone Press.

Fournet, J.-L. (1999). Hellénisme dans l'Egypte du VIe siècle: La bibliothèque et l'oeuvre de Dioscore d'Aphrodité. 2 vols. Cairo: Institut français d'archéologie orientale.

Franken, N. (1994). Aequipondia: Figürliche Laufgewichte römischer und frühbyzantinischer Schnelleewaagen. Alfter: VDG Verlag und Datenbank für Geisteswissenschaften.

Gabra, G. (2014). "Introduction." In Coptic Civilization: Two Thousand Years of Christianity in Egypt, edited by G. Gabra, 17. Cairo: American University in Cairo Press.

Gabra, G., and M. Eaton-Krauss. (2007). The Treasures of Coptic Art. Cairo: American University in Cairo Press.

Gagos, T., and D. S. Potter. (2006). "Documents." In A Companion to the Roman Empire, edited by D. S. Potter, 45-74. Malden, MA: Blackwell.

Garland, L. (1999). Byzantine Empresses: Women and Power in Byzantium, a.d. 527-1204. London and New York: Routledge.

Gittings, E. A. (2003a). "Civic Life: Women as Embodiments of Civic Life." In Byzantine Women and Their World, edited by I. Kalavrezou, 35-65. Cambridge: Harvard University Art Museums; New Haven: Yale University Press. 
Gittings, E. A. (2003b). "Helena and Fausta." In Byzantine Women and Their World, edited by I. Kalavrezou, 58-59. Cambridge: Harvard University Art Museums; New Haven: Yale University Press.

Gittings, E. A. (2003c). "Statuette of an Imperial Woman." In Byzantine Women and Their World, edited by I. Kalavrezou, 86-87. Cambridge: Harvard University Art Museums; New Haven: Yale University Press.

Haas, C. (1997). Alexandria in Late Antiquity: Topography and Social Conflict. Baltimore and London: Johns Hopkins University Press.

Habib, R. (1967). The Coptic Museum: A General Guide. Cairo: General Organization for Government Printing Offices.

Hanna, E. E. Y. (2017). "Women in Late Antique Egypt through Coptic Artefacts: A Social-Context, Art Historical Study of Women's Representations in Late Antiquity." $\mathrm{PhD}$ diss., University of Sussex.

Heinen, H. (1991). "Alexandria in Late Antiquity." In The Coptic Encyclopedia, edited by A. S. Atiya, 1:95-102. New York: Macmillan.

Heintz, F. (2000). "Investigating a Unique Byzantine Weight." The Celator 14, no. 10: 26-28.

Hermitage Museum and Pushkin Museum (1990). Decorative and Applied Art from Late Antiquity to Late Gothic. Exhibition catalogue. Leningrad and Moscow: State Hermitage Museum and State Pushkin Museum.

Herrin, J. (2000). "The Imperial Feminine in Byzantium." Past \& Present 169 (Nov.): 3-35.

Herrin, J. (2001). Women in Purple: Rulers of Medieval Byzantium. Princeton and Oxford: Princeton University Press.

Holum, D. W. (1982). Theodosean Empresses: Women and Imperial Dominion in Late Antiquity. Berkeley: University of California Press.

Hunter-Crawley, H. (2017). "Movement as Sacred Mimesis at Abu Mena and Qal'at Sem'an." In Excavating Pilgrimage: Archaeological Approaches to Sacred Travel and Movement in the Ancient World, edited by T. M. Kristensen and W. Friese, 187-202. London: Routledge.

James, L. (2010). "Byzantium: A Very, Very Short Introduction." In A Companion to Byzantium, edited by L. James, 1-8. Malden, MA: Wiley-Blackwell. 
Julian the Apostate. (1962). The Works of the Emperor Julian in Three Volumes. (4th century). Translated by W. C. Wright. Vol. 1. Cambridge, MA, and London: Harvard University Press.

Kalavrezou, I. (2002). "Images of Women in Byzantium." In Everyday Life in Byzantium, edited by D. Papanikola-Bakirtzi, 241-249. Athens: Thessaloniki White Tower.

Kalavrezou, I. (2003a). "Portrait of a Woman in a White Tunic." In Byzantine Women and Their World, edited by I. Kalavrezou, 243. Cambridge: Harvard University Art Museums; New Haven: Yale University Press.

Kalavrezou, I. (2003b). "Women in the Visual Record of Byzantium." In Byzantine Women and Their World, edited by I. Kalavrezou, 13-21. Cambridge: Harvard University Art Museums; New Haven: Yale University Press.

Keenan, J. G. (2007). "Byzantine Egyptian Villages." In Egypt in the

Byzantine World, 300-700, edited by R. S. Bagnall, 226-243. Cambridge: Cambridge University Press.

Kleiner, F. S. (2015). Gardner's Art through the Ages: The Western Perspective. 15th ed. Vol. 1. Boston: Cengage Learning.

MacCoull, L. S. B. (1988). Dioscorus of Aphrodito: His Works and His World. Berkeley: University of California Press.

Maguire, E. D., et al. (1999). Weavings from Roman, Byzantine, and Islamic Egypt: The Rich Life and the Dance. Champaign: University of Illinois.

Maguire, H. (2007). "The Good Life." In Late Antique and Medieval Art of the Mediterranean World, edited by E. R. Hoffman, 6384. Oxford: Blackwell.

Mango, C. (1986). The Art of the Byzantine Empire 312-1453: Sources and Documents. Medieval Academy Reprints for Teaching 16. Toronto: University of Toronto Press.

Mango, C. (2002). "Introduction." In The Oxford History of Byzantium, edited by C. Mango, 1-16. Oxford and New York: Oxford University Press.

McClanan, A. L. (1997). "Empress, Image, State: Imperial Women in the Early Medieval World" PhD diss., Harvard University.

Merhav, R. (1981). A Glimpse into the Past: The Joseph Ternbach Collection. Jerusalem and Chicago: Israel Museum.

Mietke, G. (2000). "Plaque de plafond à caisson, avec deux bustes" In L'Art copte en Égypte: 2000 ans de christianisme, exhibition catalogue, 155. Paris: Institut du Monde Arabe and Éditions Gallimard. 
Miguélez-Cavero, L. (2008). Poems in Context: Greek Poetry in the Egyptian Thebaid 200-600 ad. Berlin and New York: Walter de Gruyter.

Morgan, R. (2016). History of the Coptic Orthodox People and the Church of Egypt. Victoria: Friesen Press.

Nevett, L. C. (2010). Domestic Space in Classical Antiquity. Ann Arbor: University of Michigan Press.

Palme, B. (2007). "The Imperial Presence: Government and Army." In Egypt in the Byzantine World, 300-700, edited by R. S. Bagnall, 244-270. Cambridge: Cambridge University Press.

Paulinus of Nola. (1975). The Poems of St. Paulinus of Nola. Translated by P. G. Walsh. New York and Ramsey, NJ: Newman Press.

Petrina, Y. (2014). "Jewellery from Late Antique Egypt." BMSAES 21: $31-43$.

Procopius. (1981). The Secret History. Translated by G. A. Williamson. Reprint, London: Penguin.

Rouse, W. H. D. (1940). Nonnos, Dionysiaca. Loeb Classical Library 1. Cambridge: Harvard University Press.

Rowlandson, J. (1998). Women and Society in Greek and Roman Egypt. Cambridge: Cambridge University Press.

Rutschowscaya, M. H. (2000). "Stèle funéraire à l'orante" In L'Art copte en Égypte: 2000 ans de christianisme, exhibition catalogue, 125. Paris: Institut du Monde Arabe and Éditions Gallimard.

Schroeder, J. A. (2014). Deborah's Daughters: Gender Politics and Biblical Interpretation. Oxford: Oxford University Press.

Shelton, K. J. (1979). "The Projecta Casket" In Age of Spirituality: Late Antique and Early Christian Art, Third to Seventh Century, edited by K. Weitzmann, 330-332. New York: Metropolitan Museum of Art.

Stocker, C. W. (1839). The Satires of Juvenal and Persius, from the Texts of Ruperti and Orellius, London: Longman.

Thomas, T. K. (2007). "Coptic and Byzantine Textiles Found in Egypt" In Egypt in the Byzantine World, 300-700, edited by R. S. Bagnall, 137-162, Cambridge: Cambridge University Press.

Thomas, T. K., and D. G. Harding. (1990). Textiles from Medieval Egypt ad 300-1300. Pittsburgh: Carnegie Museum of Natural History.

Tigghelaar, E. J. C. (2003). "The White Dress of the Essenes," In Jerusalem, Alexandria, Rome: Studies in Ancient Cultural Interaction in Honour of A. Hilhorst, edited by F. García Martínez and G. P. Luttikhuizen, 301-322. Journal for the Study 
of Judaism in the Persian, Hellenistic, and Roman Periods, Supplements 82. Leiden: Brill, 2003.

Török, L. (2005). Transfiguration of Hellenism, Leiden and Boston: Brill.

Török, L., et al. (2005). After the Pharaohs: Treasures of Coptic Art from Egyptian Collections. Budapest: Museum of Fine Arts.

Weitzmann, K. (1972). Catalogue of the Byzantine and Early Mediaeval Antiquities in the Dumbarton Oaks Collection, Washington, DC: Dumbarton Oaks Center for Byzantine Studies. Wilber, D. N. (1940). "The Coptic Frescoes of Saint Menas at Medinet Habu" The Art Bulletin 22, no. 2: 86-103.

Wildberg, C. (2016). "Neoplatonism" In The Stanford Encyclopedia of Philosophy, edited by E. N. Zalta, Spring 2016 ed. https://plato.stanford.edu/archives/spr2016/entries/neoplatonism/ $22 / 2 / 2016$

Wilfong, T. (2002). Women of Jeme: Lives in a Coptic Town in Late Antique Egypt. Ann Arbor: University of Michigan Press.

Zwirn, S. R. (1979a). "Apse Decoration of S. Vitale" In Age of Spirituality: Late Antique and Early Christian Art, Third to Seventh Century, edited by K. Weitzmann, 76-77. New York: Metropolitan Museum of Art.

Zwirn, S. R. (1979b). "The Empress Theodora and Members of Her Court." In Age of Spirituality: Late Antique and Early Christian Art, Third to Seventh Century, edited by K. Weitzmann, 77-78. New York: Metropolitan Museum of Art. 


\section{FigURES}

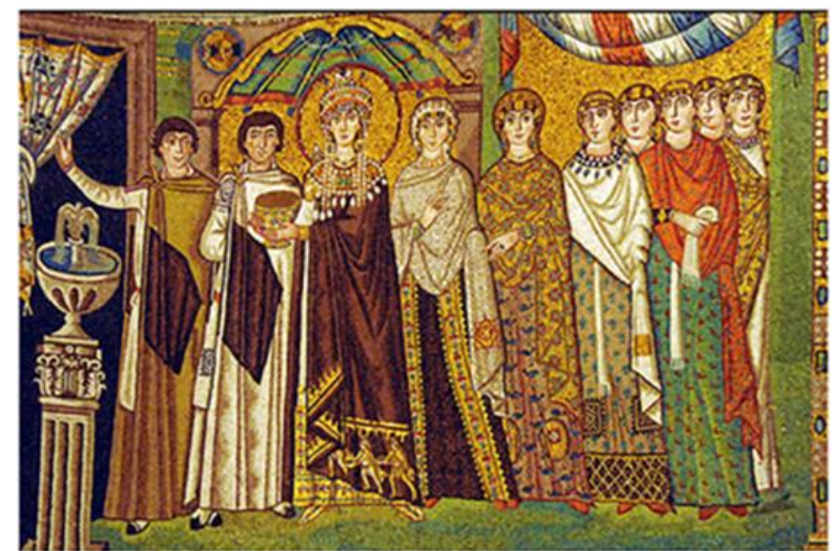

Fig 1: Apse mosaic of S. Vitale showing Theodora and her retinue Kleiner 2015: 267

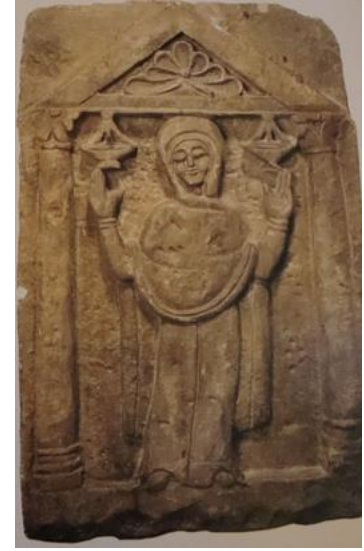

Fig 2: A limestone funerary stela from al-Fayoum, or Saqqara, showing typical women's clothing Bénazeth 2000: 127, fig. 104

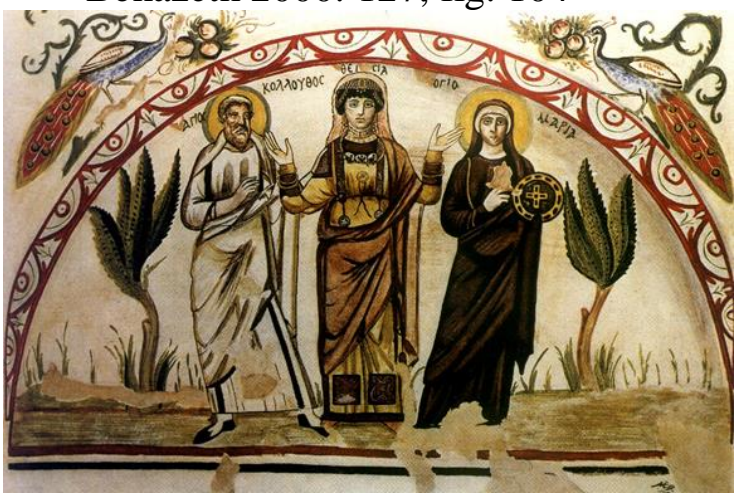

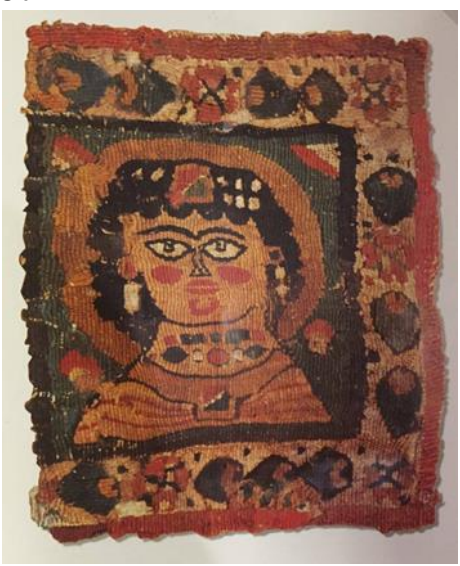

Fig 3: Tapestry portrait bust from Rose Choron's private collection Maguire 1999: 156, fig. C 15
Fig 4: A mural painting from Antinopolis showing women's dress decoration

Bénazeth 2000: 106-107 


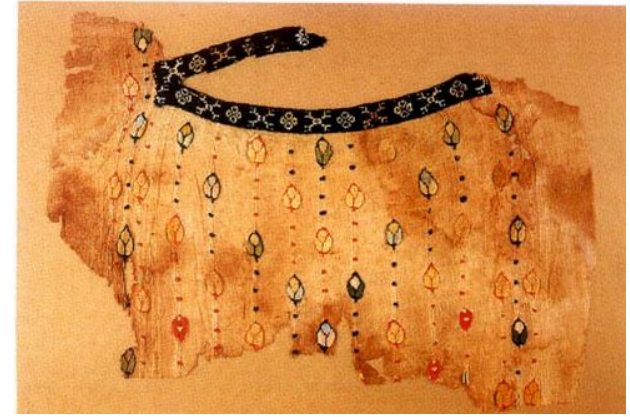

Fig 5: A fragment of a garment from Antinopolis, Du Bourguet 1964: fig. 198

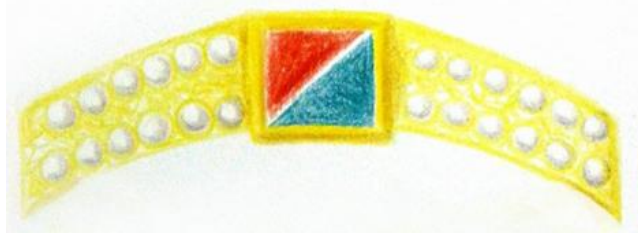

Fig 7: Restored perspective, detail of a crown adorning the head of a woman on a tapestry portrait-bust (fig. 3).

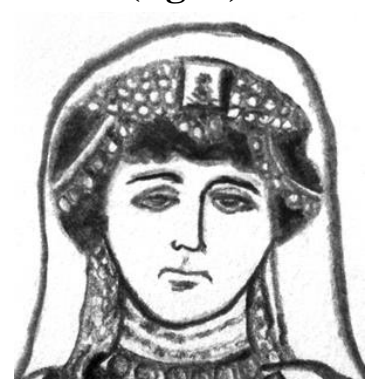

Fig 9: Detail of Theodosea's hairstyle on Antinopolis mural (fig. 4).

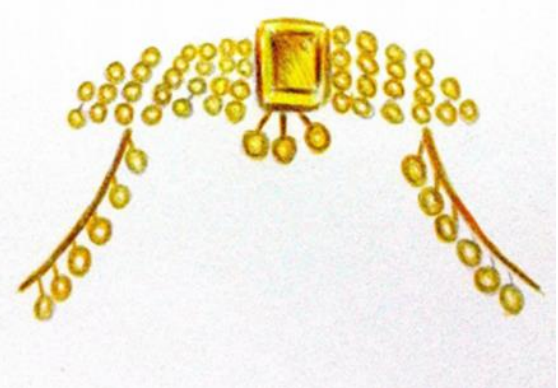

Fig 6: Restored perspective, detail of the golden hairnet of Theodosea in Antinopolis mural (fig. 4).

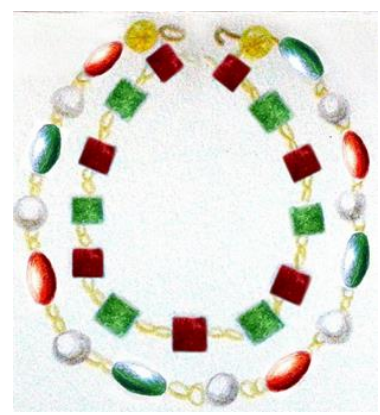

Fig 8: Restored perspective, detail of a necklace of a woman on a tapestry portrait-bust (fig. 3).

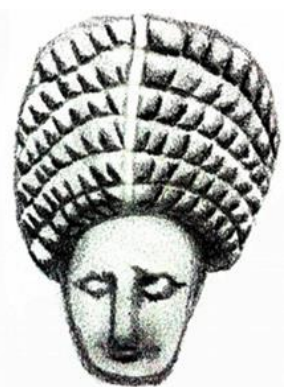

Fig 10: Head of a hairpin in the form of a head of a woman with elaborate hairstyle

Weitzmann 1972: 26, fig. 14 


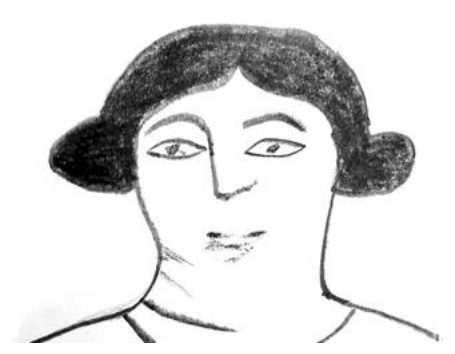

Fig 11: Detail of a head of a woman on the lid of a casket Mietke 2000: 15, fig. 144

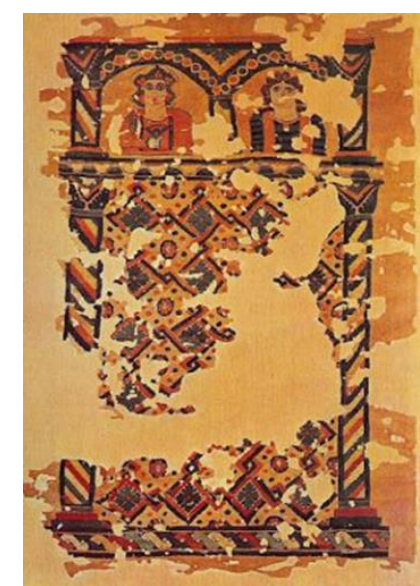

Fig 13: Large wall hanging showing a wealthy couple Calament 1996: 38

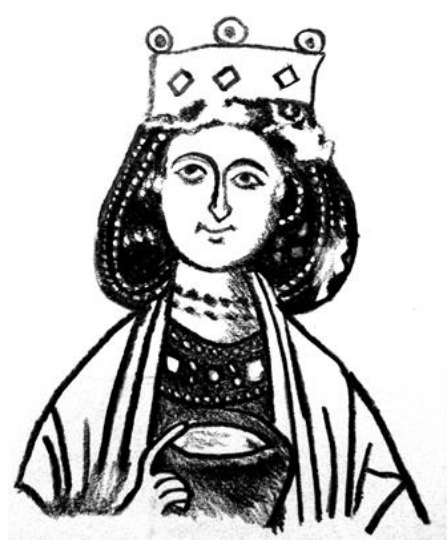

Fig 15: The personification of Church from a mural painting in Baouit

Clédat 1904: 13-29, pl. 14

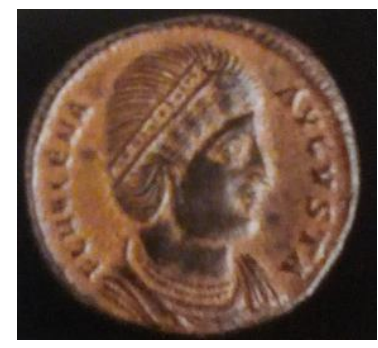

Fig 12: A bronze Follis of the Empress Helena with Securitas,

Mint of Antioch, 325-26

Gittings 2003b: 58-59, fig. 16

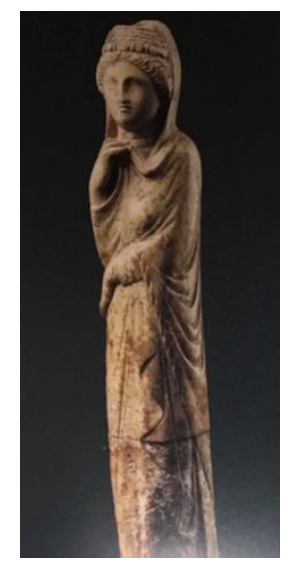

Fig 14: A statuette of an imperial woman

Gittings 2003c: 86-87, fig. 28

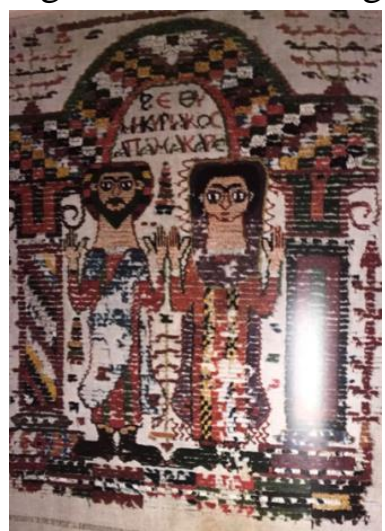

Fig 16: Looped pile hanging showing a praying couple. Cortopassi and Tsourinaki 2002: 278-279, no. 291 


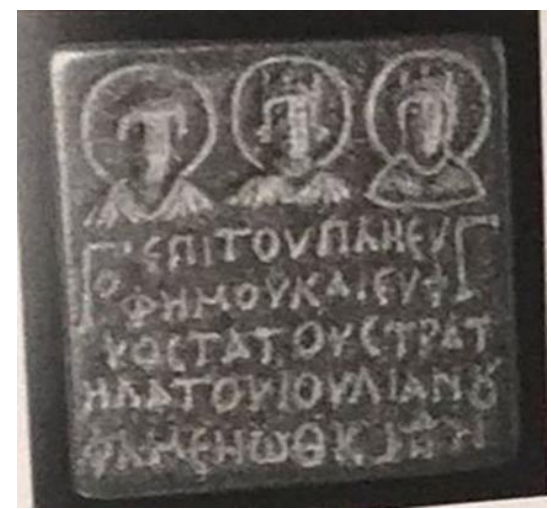

Fig 17: Weight with imperial busts and local official

Heintz 2000: 14, no. 10:26-28

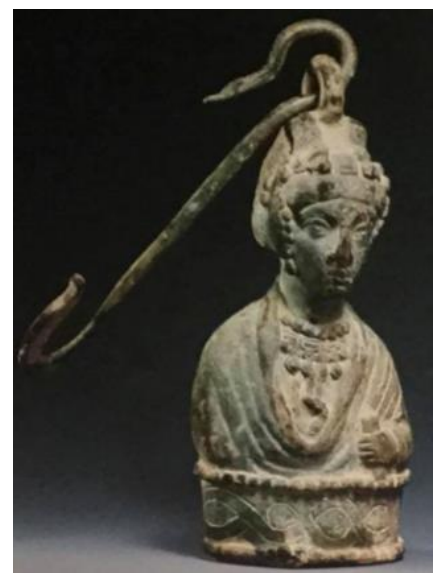

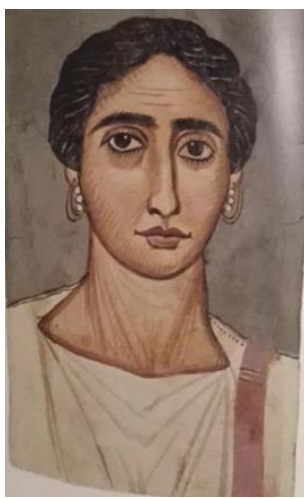

Fig 18: Portrait of a female teacher or philosopher

Kalavrezou 2003a: 243, fig. 134

Fig 19: Empress bust weight Hermitage Museum and Pushkin Museum 1990: 22, cat. 7, pl. 23 